\title{
Bird, reptile and mammal remains from archaeological sites on Rapa Island
}

\author{
Alan J. D. Tennyson \\ Museum of New Zealand Te Papa Tongarewa, Wellington, New Zealand, AlanT@tepapa.govt.nz \\ Atholl Anderson \\ Department of Archaeology and Natural History, The Australian National University
}

\section{Introduction}

Rapa Island, French Polynesia, has a land vertebrate fauna typical of an isolated oceanic South Pacific Island. Birds dominate the fauna and there are no native mammals or terrestrial reptiles. Together with its smaller offshore islands, Rapa has a small, poorly known but important bird fauna. Bird species recorded breeding or as migrant residents are: Christmas shearwater Puffinus nativitatis, little shearwater Puffinus assimilis myrtae, Kermadec petrel Pterodroma neglecta neglecta, Murphy's petrel Pterodroma ultima, black-winged petrel Pterodroma nigripennis, whitebellied storm petrel Fregetta grallaria titan, Polynesian storm petrel Nesofregetta fuliginosa, red-tailed tropicbird Phaethon rubricauda, grey duck Anas superciliosa, spotless crake Porzana tabuensis, golden plover Pluvialis fulva, wandering tattler Tringa incana, brown noddy Anous stolidus, grey noddy Procelsterna cerulea, white tern Gygis alba, Rapa fruit dove Ptilinopus huttoni and long-tailed cuckoo Eudynamys taitensis (Pratt et al. 1987; Thibault and Varney 1991b). The fruit dove and the subspecies of little shearwater and white-bellied storm petrel are endemic to the island group.

The history of introduced mammals on Rapa is sketchy but Pacific rats (Rattus exulans) arrived in prehistoric times and, apparently, are still the only rat species present today (Thibault and Varney 1991a, 1991b). At times, rats have been 'very numerous' (Hall 1869). There is no historical evidence suggesting the pre-European introduction of dogs (Canis familiaris), pigs (Sus scrofa) or chickens (Gallus gallus). These were introduced in the 19th century, along with sheep (Ovis aries), which 'did not seem to thrive' (Hall 1869:80), cattle (Bos taurus) and goats (Capra hircus). The latter are now in large numbers and the vegetation and integrity of upland soils is suffering considerably as a result. Cats (Felis catus) were introduced at an unknown date but were established by 1921 (Holyoak and Thibault 1984).

Vertebrate remains recovered by archaeological excavations in the coastal sites were mainly 
of fish, but bird and rat bones were also quite common. Here, we report the identification and quantification of bird, reptile and mammal bone.

\section{Methods}

Comparative collections in the Museum of New Zealand Te Papa Tongarewa (NMNZ) were used by Tennyson to identify faunal remains. Specimens of closely related taxa were used when comparative skeletons of species known from Rapa were not available. Numbers of individual birds given represent only the minimum number of individuals based on the fragmentary remains collected. When calculating minimum numbers of individuals, identifications to a probable species were lumped with certain identifications of that species.

\section{List of main comparative skeletons used (NMNZ unless otherwise noted)}

Pink-footed shearwater Puffinus creatopus OR.27754; flesh-footed shearwater Puffinus carneipes S.771, OR.26448; wedge-tailed shearwater Puffinus pacificus OR.16209, OR.27270, OR.27271; Christmas shearwater OR.24682; little shearwater OR.23972, OR.24230; Audubon's shearwater Puffinus therminieri OR.27467, OR.27551; black-winged petrel OR.24226; Kermadec petrel OR.11423, OR.25216; Murphy's petrel OR.24403; white-bellied storm petrel OR.16071, OR.27781; Polynesian storm petrel OR.27482, OR.27504; white-tailed tropicbird OR.27835; red-tailed tropicbird OR.16056; red-footed booby Sula sula OR.24594; brown booby Sula leucogaster OR.16058; domestic chicken Gallus gallus OR.16485; banded rail Gallirallus philippensis OR.22842; spotless crake OR.26455, OR.27985a; golden plover OR.22509; wandering tattler OR.26437; sooty tern Sterna fuscata OR.22945; brown noddy OR.25348; black noddy Anous minutus OR.23958; grey noddy OR.24377; white tern OR.23699; Cook Islands fruit dove Ptilinopus rarotongensis OR.22463; extinct Fijian pigeon Ducula lakeba S.39286; collared lory Phigys solitarius Fiji Museum 22; Horned parakeet Cyanoramphus cornutus OR.25730; long-tailed cuckoo OR.18339; hawksbill turtle Eretmochelys imbricata RE.5307; Norway rat Rattus norvegicus LM.1274; dog LM.1412; cat LM.807, LM.808, LM.1413, LM.1414; pig LM.1410, Canterbury Museum FMa 4086; goat LM.539, ex D.S.I.R. collection no.4494.

\section{Identification of taxa}

Spits within excavations are shown in brackets for identified taxa. S-numbers are NMNZ accession codes. All rat remains were assumed to be Pacific rat, based on their small size.

Abbreviations. cf. $=$ similar to and probably, juv $=$ juvenile, prox $=$ proximal, dist $=$ distal, $\mathrm{L}=$ left, $\mathrm{R}=$ right, $\mathrm{pt}=$ part, frag $=$ fragment, $\mathrm{cra}=$ cranium, $\mathrm{pmx}=$ premaxilla, mand $=$ mandible, quad = quadrate, vert $=$ vertebra, cor $=$ coracoid, scap $=$ scapula, ster $=$ sternum, hum $=$ humerus, uln = ulna, $\mathrm{rad}=$ radius, $\mathrm{cmc}=$ carpometacarpus, alphal $=$ alar phalange, pel $=$ pelvis, fem $=$ femur, tbt $=$ tibiotarsus, fib $=$ fibula, tmt $=$ tarsometatarsus, phal $=$ phalanx .

\section{Tangarutu Cave}

\section{Location T1}

Location $\mathrm{T} 1$ in loose sand at base of main exposure directly below eroding pocket of bones exposed at 155-160 cm depth. The loose bones were:

Kermadec petrel: 4 L 1 juv R 1 R hum, 3 R uln, 1 L rad, 2 R cmc; S.44406.

red-tailed tropicbird: 1 ster; S.44407.

Unidentified remains: S. 44408 . 
Additional material excavated from the face of T1 at 155-160 cm depth:

flesh-footed/pink-footed shearwater: 1 skull, 1 mand, 1 L 1 R hum, 1 L 1 R uln, 1 rad, 1 pel, 1

$\mathrm{R}$ fem, $1 \mathrm{R}$ tbt, 1 toe; S.44391.

little shearwater: 1 dist $\mathrm{R}$ hum, $1 \mathrm{R}$ uln, $1 \mathrm{R}$ rad; $\mathrm{S} .44403$.

Kermadec petrel: 1 frag mand, 1 furcula, 2 R cor, 7 dist L 6 dist R hum, 9 L 5 R uln, 7 L 7 R rad, 6 L 6 R cmc, 6 L 3 R manus, 4 alphal; S.44404.

Unidentified remains: S.44405, S.44409.

\section{Excavation E1}

little shearwater: 1 shaft uln (1), 1 prox rad (1), $1 \mathrm{R}$ cmc (14); S.44416, S.44451.

black-winged petrel: 1 pt cra (1), 1 mand (10), 2 R scap (14), 1 pt L 1 pt R 1 R cor (16), 2 pt L 1 R hum (17), 1 L uln (18), 1 dist rad (19), 1 R cmc 2 (19), manus (19), 1 pel (16), 1 dist L $2 \mathrm{~L} 1 \mathrm{R}$ fem (16), 1 prox L 1 dist L 1 shaft L 1 prox R 1 dist R $1 \mathrm{R}$ tbt (18), $2 \mathrm{R}$ tmt (21); S.44417, S.44434-35, S.44450, S.44459, S.44467, S.44475-76, S.44487, S.44489, S.44541, S.44544, S.44553, S.44558.

Kermadec petrel: 3 pt mand (1), 2 R quad (7), 2 pt furcula (10), 2 L scap (13), 1 L 3 pt R cor (14), 1 R scap (14), 1 frag ster (14), 1 prox L 1 L 2 prox R 1 frag R 2 R hum (16), 3 dist L 2 L 2 dist $\mathrm{R} 1 \mathrm{R}$ uln (17), 2 dist $\mathrm{R} 1$ prox $\mathrm{R}$ rad (18), 2 dist $\mathrm{L} 2$ prox $\mathrm{R} 1$ dist $\mathrm{R} 1 \mathrm{R}$ cmc (18), 1 manus (19), 3 alphal (14), 1 pt pel (14), $1 \mathrm{R}$ fem (15), 2 prox L 2 dist L 4 dist R tbt (16), 1 fib (17), 3 pt L 2 R tmt (16), 5 toes (16); S.44412, 44429, S.44433, S.44445, S.44449, S.44458, S.44466, S.44474, S.44484, S.44486, S.44491, S.44536, S.44539, S.44543, S.44547, S.44552.

red-tailed tropicbird: 1 pt mand (1), 1 prox L hum (14), 1 dist L hum 1 (14), shaft cmc (21); S.44413, S.44452, S.44492, S.44537.

spotless crake: 1 dist L tbt (11); S.44596.

brown noddy: $1 \mathrm{R}$ scap (3), $1 \mathrm{R}$ rad (3), 1 dist $\mathrm{R}$ cmc (17), 2 dist $\mathrm{R}$ tbt (18), 1 dist $\mathrm{R}$ tmt (16); S.44422, S.44468, S.44477, S.44545.

grey noddy: 1 cor (13); S.44446.

white tern: 1 pt pmx (11), 2 pt mand (15), 2 L cor (17), 1 L scap (18), 2 dist L hum (17), 1 L cmc (17), 1 manus (17); S.44439, S.44456, S.44469, S.44478, S.44548, S.44556.

Rapa fruit dove: 1 pt L cor (13), 1 R cmc (18); S.44447, S.44480.

pigeon (cf. Ducula): 1 prox L fem (14), 1 toe (16); S.44453, S.44461.

parrot (cf. Cyanoramphus): 1 dist L tbt (18); S.44481.

Unidentified bird feathers: S.44418, S.44420, S.44423, S.44426-27.

rat: 1 cra, 9 mand, 2 teeth, 5 vert, 2 hum, 1 pt pel, 2 fem; S.44436, S.44438, S.44441, S.44443, S.44460, S.44464, S.44470, S.44482, S.44528, S.44534, S.44538, S.44549.

cf. Goat: 1 pel; S.44415.

Unidentified mammal fur: S.44424.

turtle: 1 ?uln, 1 piece of plastron; S.44414, S.44483.

Unidentified remains: S.44419, S.44421, S.44425, S.44428, S.44430-31, S.44437, S.44440, S.44442, S.44444, S.44448, S.44454-55, S.44457, S.44462-63, S.44465, S.44471-73, S.44479, S.44485, S.44488, S.44490, S.44493, S.44529-33, S.44535, S.44540, S.44542, S.44546, S.44550-51, S.44554-55, S.44557, S.44559.

\section{Excavation E2}

black-winged petrel: 1 dist R hum (10-13); S.44515.

Kermadec petrel: 1 pt L scap (4), 1 shaft L 1 L 1 R cor (8-9), 1 prox L 1 pt R hum (10-13), 1 dist $\mathrm{R}$ uln (14), 1 pt pel (16-17), 1 dist L tmt (23-25); S.44504, S.44510-11, S.44514, 
S.44518, S.44520-21, S.44564.

1 red-tailed tropicbird: 1 vert (9), 1 alphal (22), 1 pt pel (23-25); S.44512, S.44562, S.44565. parrot (cf. Cyanoramphus): 1 prox $\mathrm{R}$ uln (10-13), $1 \mathrm{R}$ rad (14); S.44516, S.44560.

Unidentified bird toes: S.44500, S.44526.

Unidentified feathers: S.44392-93, S.44494, S.44497, S.44501.

rat: 2 mand (1), 1 tooth (1), 2 pt pel (18), 1 tibia (14); S.44495, S.44498, S.44523, S.44561.

Unidentified remains: S.44496, S.44499, S.44502-03, S.44505-09, S.44513, S.44517, S.44519, S.44522, S.44524-25, S.44563, S.44566.

\section{Excavation RI}

little shearwater: $1 \mathrm{~L}$ fem (4), 1 prox R fem (7); S.44574, S.44578.

black-winged petrel: 1 L cor (3), 1 dist L hum (4), 1 dist R hum (8); S.44571, S.44573, S.44580.

Kermadec petrel: 1 quad (1), 2 L 1 R cor (3), 1 L scap (4), 1 dist L 1 frag R hum (6), 1 dist $\operatorname{rad}(7), 1$ pel (8), 1 dist R fem (8), 1 toe (8); S.44567, S.44570, S.44572, S.44575, S.44577, S.44579, S.44582.

Unidentified remains: S.44410-11, S.44568, S.44569, S.44576, S.44581.

\section{Excavation $S 1$}

little shearwater: 1 ster (3); S.44362.

black-winged petrel: 1 L scap, 1 ster, 1 pel (all 3); S.44396.

Kermadec petrel: 3 frag cra, $1 \mathrm{~L}$ scap, 3 ster, 1 dist L uln, 1 dist $\mathrm{L}$ rad, $3 \mathrm{~L} \mathrm{cmc}, 1$ prox L tmt toe (all 3); S.44395.

white-bellied storm petrel: $1 \mathrm{~L}$ cor (3); S.44397.

red-tailed tropicbird: $1 \mathrm{~L}$ cor (3); S.44398.

rail (cf. Gallirallus): $1 \mathrm{~L}$ tmt (3); S.44399.

pigeon: 1 frag ster (3); S.44400.

rat: 1 dist fem (3); S.44401.

Unidentified remains: S.44402.

\section{Akatanui shelters}

Shelter 1

white-bellied storm petrel: 1 dist hum (2); S.43679.

?chicken: 2 toes (2); S.43680.

rat: 2 teeth, 1 pel, 2 tibia (1); S.43676-77, S.43685.

cat: 1 pt maxilla (1); S.43674.

Unidentified mammal: 1 rib, 1 phal; S.43682.

Unidentified remains: S.43675, S.43678, S.43681, S.43683-84, S.43686.

Shelter 3 Square A1

rat: 1 tooth (1), 1 scap (1), 2 hum (1), 2 pel (2), 3 fem (2), 1 tibia (2); S.43688, S.43690, S.43692, S.43694.

Unidentified bird feathers: S.43687, S.43691.

Unidentified remains: S.43689, S.43693, S.43695.

Shelter 3 Square B1

grey noddy: 1 dist hum (1); S.43696.

Unidentified bird feathers: S.43697, S.43703. 
rat: 3 mand (1), 1 tooth (1), 1 vert (1), 1 pel (2), 2 fem (2), 1 tibia (2); S.43699, S.43701, S.43705, S.43708.

Unidentified mammal: 1 juv vert, fur; S.43704, S.43706.

Unidentified remains: S.43698, S.43700, S.43702, S.43707.

Shelter 3 Square C1

white-bellied storm petrel: 1 prox tmt (2); S.43713.

grey noddy: 1 prox L hum (1); S.43709.

rat: 1 skull (1), 1 mand (1), 3 scap (2), 1 hum (2), 2 fem (2), 3 tibia (3); S.43710, S.43715, S.43719-20.

?pig: 1 tooth (1); S.43712.

Unidentified mammal: 1 juv hum, fur; S.43714, S.43716.

Unidentified remains: S.43711, S.43717-18, S.43721.

Shelter 3, Test-pit E1

little shearwater: $1 \mathrm{R}$ fem (1); S.43723.

Kermadec petrel: 1 dist R cmc (2); S.43728.

red-tailed tropicbird: 1 shaft R uln (1); S.43724.

rat: 2 mand, 1 tooth, 1 prox fem, 1 dist tibia (all 1); S.43722, S.43726.

cf. goat: 2 vert, 2 rib (both 1); S.43725.

Unidentified remains: S.43727, S.43729.

\section{Angairao Bay shelters}

\section{Shelter $C$}

little shearwater: 1 pt cra, 1 dist L rad (both 2); S.44366, S.44368.

black-winged petrel: 1 dist L 1 dist R tbt (3); S.44372.

white-bellied storm petrel: 1 dist tbt (2); S.44367.

rat: 2 pt cra (2), 2 mand (2), 3 teeth (2), 4 vert (2), 1 hum (2), 1 pel (2), 3 fem (3), 4 tibia (3); S.44364, S.44370, S.44373.

cf. goat: 1 vert (2); S.44375.

Unidentified remains: S.44365, S.44369, S.44371, S.44374.

Shelter $E$

rat: 1 vert (9); S.44386.

cf. goat (juv) (4); S.44376, S.44379.

turtle: 1 piece of plastron (4); S.44380.

Unidentified remains: S.44377-78, S.44381-85.

Noogoriki

little shearwater: $1 \mathrm{cmc}(1)$; S. 44388 .

Unidentified bird feather: S.44389.

Unidentified remains: S.44387, S.44390.

\section{Taugatu Shelter}

Unidentified remains: S.44527. 


\section{Discussion and conclusions}

It is not certain that all of the bird bones recovered from the Rapa sites had been deposited as midden rather than by natural accumulation. No bones showed clear signs of charring or human butchery and elements from all skeletal components were preserved. However, the clear cultural context of the sites and the presence of introduced mammal remains, particularly of rat (cf. Rattus exulans), throughout the stratigraphy show that the deposits were at least laid down after human settlement. Of domestic animals, the chicken was identified tentatively by two toe bones recovered at a shallow depth $(10-20 \mathrm{~cm})$ in Akatanui Shelter 1, where there was also material from the European era, including a spectacle lens, iron nails and a button. A cat maxilla was also found $(0-10 \mathrm{~cm})$ at this site. A probable pig tooth occurred in the surface spit $(0-10$ $\mathrm{cm})$ at Akatanui Shelter 3. Goat bones were the most common of introduced faunal material, occurring in surface deposits at Akatanui, Test-pit E1, at Tangarutu E1 in surface sand and at Angairao Shelter E, where the remains were at 30-40 cm depth below an oven. No dog bone was recovered and the ethnographic evidence that Rapa had no introduced mammals other than the Pacific rat before European arrival is sustained by the archaeological data. No seal bone was recorded.

The reptile remains were exclusively from marine turtle. Plastron at Angairao Shelter E occurred in conjunction with goat bone (above), but at Tangarutu excavation E1 it was recovered from near the base of the site, in Spit 18. Turtles are not common around Rapa, but still the scarcity of their remains in the sites is surprising.

Fifteen species of birds, represented by a total of 118 individuals, were identified by remains from all sites combined (Table 6.1). Most bones identified were of species currently breeding at Rapa (Pratt et al. 1987; Thibault and Varney 1991b), and most (90\%) of the bird remains identified were seabirds. The dominant species was Kermadec petrel, comprising almost half of all avian remains. As this petrel is one of the more common seabirds breeding on Rapa today (Thibault and Varney 1991b), its prevalence in the deposits is not surprising.

The little shearwater bones are presumed to be from the race endemic to Rapa. This is a poorly known bird that currently only breeds on a few small islets off the main island (Thibault and Varney 1991b). Black-winged petrels breed on some of the islets offshore from Rapa today (Thibault and Varney 1991b). The species is undergoing a rapid expansion in its breeding range (e.g. Jenkins and Cheshire 1982; Tennyson 1991), but the remains identified in this study demonstrate that the Rapa population has been long-standing and therefore is not a new colonisation, contrary to the conclusions of Thibault and Varney (1991b). Red-tailed tropic birds, grey noddies, brown noddies and white terns are also common seabirds currently breeding on Rapa (Thibault and Varney 1991b).

The four storm petrel bones identified are larger than the bones of the white-bellied storm petrel subspecies breeding at the Kermadec and Juan Fernandez islands and smaller than bones of the Polynesian storm petrel, so they are consistent with the large endemic white-bellied subspecies breeding on islets off Rapa (Murphy and Snyder 1952; Thibault and Varney 1991b). However, the flesh-footed or pink-footed shearwater specimen is a surprising find. Rapa is thousands of kilometres outside the normal range of both these species, which breed to the west and east of Rapa respectively (Marchant and Higgins 1990). Both species are migrants perhaps their migration route takes them nearer Rapa than previously realised. If so, the Rapa specimen may be a vagrant. Alternatively, Rapa might be a former breeding location of one or other species. 
Two rail bones were identified. The tarsometatarsus is similar to but smaller than that of a banded rail. Therefore, it seems likely that an endemic form, in the widespread genus Gallirallus, was once resident on Rapa. Estimates of the number of extinct rails in Oceania range from 200 to 3000 (Steadman 1995; Tennyson and Martinson 2006), so an extinct form on Rapa is to be expected. The only rail known from Rapa today is the much smaller spotless crake (Pratt et al. 1987), which was represented by one distal tibiotarsus.

The smaller pigeon bones were assigned, on the basis of size alone, to the sole extant dove on Rapa. In addition, at least one other larger species of pigeon, similar to a large Ducula species, once occurred. Large Ducula species have been eliminated from several of the Pacific Islands (e.g. Worthy 2001), so an extinct species on Rapa might be expected. The fragmentary pigeon sternum of unknown relationships (S.44400 from Spit 3 of excavation S1 at Tangarutu) has a low, rounded keel, indicating that this species may have had reduced powers of flight.

The three parrot bones are the first evidence that any parrots once lived in the Austral Island group. Few parrot species occur in Eastern Polynesia and those that do (or did) belong to the genera Vini (lorikeets) and Cyanoramphus (parakeets) (Pratt et al. 1987). The Rapa bones fit Cyanoramphus well, so they probably represent an extinct endemic species and extend the range of this genus further east than previously known. Both Cyanoramphus species recorded from tropical Eastern Polynesia (C. zealandicus from Tahiti and C. ulietanus from Raiatea) are also extinct (Pratt et al. 1987).

Overall, remarkably few of the resident bird species on Rapa today were missing from the archaeological samples (the missing taxa are: Christmas shearwater, Murphy's petrel, Polynesian storm petrel, grey duck, golden plover, wandering tattler and long-tailed cuckoo). The small size of the collection is likely to explain the absence of most of these species but they might also have been relatively uncommon on Rapa. As the remains of large birds are more commonly preserved in such deposits, the absence of some large taxa that are otherwise widespread in the South Pacific (e.g. wedge-tailed shearwaters, boobies and frigatebirds) could suggest that these may not have been present on Rapa.

It seems likely that further excavations will reveal more lost Rapa bird taxa because at least three extinct species were detected in this small study. The remains of the fruit dove and local subspecies of the little shearwater and white-bellied storm petrel are the first skeletal material of these taxa to be collected. They provide a basis for future reference and taxonomic work. Further work is required to determine the identity of the parrot, flesh-footed/pink-footed shearwater, Gallirallus-type rail and large pigeon. It is highly likely that the bird extinctions detected were the result of human impact and that seabird species now confined to nesting on small offshore islands previously bred on main Rapa. 
Table 6.1. Distribution by site and excavation unit of identified bird bone.

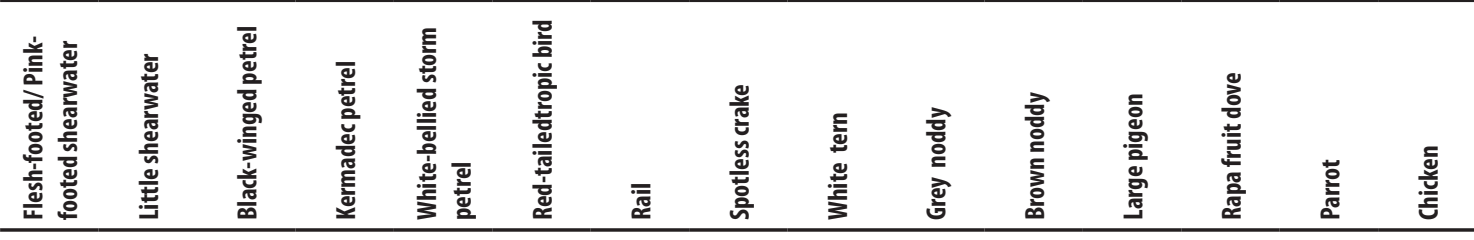

\section{Tangarutu}

Location T1

14

Excavation E1

Spit 1

Spit3

Spit 7

Spit 10

Spit 11

Spit 13

Spit 14

Spit 15

Spit 16

Spit 17

Spit18

Spit 19

Spit 21

\begin{tabular}{lllllllllllll} 
MNI Total & 1 & 3 & 11 & 38 & 4 & 6 & 1 & 4 & 2 & 2 & 1 \\
\hline
\end{tabular}

Excavation E2

Spit 4

Spits 8-9

Spits 10-13

Spit 14

Spits 16-17

Spit 22

Spits 23-25

MNI Total

16

3

Excavation R1

Spit 1

Spit3

Spit 4

Spit 6

Spit 7

Spit 8 
Table 6.1. continued

\begin{tabular}{|c|c|c|c|c|c|c|c|c|c|c|c|c|c|c|c|}
\hline & 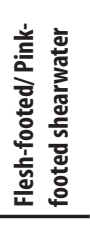 & 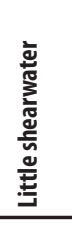 & 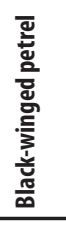 & 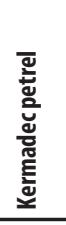 & 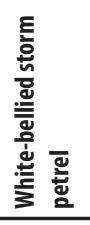 & 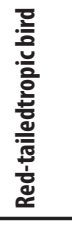 & $\overline{\overline{\widetilde{c}}}$ & 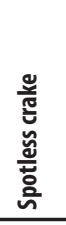 & 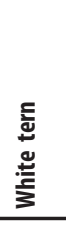 & 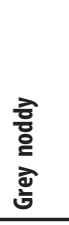 & 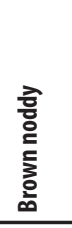 & 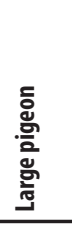 & 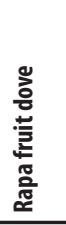 & 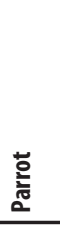 & 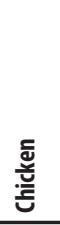 \\
\hline \multicolumn{16}{|c|}{ Excavation S1 } \\
\hline Spit 3 & & 1 & 1 & 3 & 1 & 1 & 1 & & & & & 1 & & & \\
\hline TOTAL & 1 & 6 & 16 & 54 & 1 & 8 & 1 & 1 & 6 & 1 & 4 & 3 & 2 & 3 & \\
\hline \multicolumn{16}{|l|}{ Akatanui } \\
\hline \multicolumn{16}{|l|}{ Shelter 1} \\
\hline Spit 2 & & & & & 1 & & & & & & & & & & 1 \\
\hline \multicolumn{16}{|l|}{ Shelter 3} \\
\hline Spit 1 & & 1 & & & & 1 & & & & 1 & & & & & \\
\hline Spit 2 & & & & 1 & 1 & & & & & & & & & & \\
\hline TOTAL & & 1 & & 1 & 2 & 1 & & & & 1 & & & & & 1 \\
\hline \multicolumn{16}{|l|}{ Angairao } \\
\hline \multicolumn{16}{|l|}{ Shelter C } \\
\hline Spit 2 & & 1 & & & 1 & & & & & & & & & & \\
\hline Spit 3 & & & 1 & & & & & & & & & & & & \\
\hline Noogoriki & & 1 & & & & & & & & & & & & & \\
\hline TOTAL & & 2 & 1 & & 1 & & & & & & & & & & \\
\hline \multicolumn{16}{|l|}{ ALL SITES } \\
\hline TOTAL MNI & 1 & 9 & 17 & 55 & 4 & 9 & 1 & 1 & 6 & 2 & 4 & 3 & 2 & 3 & 1 \\
\hline Per cent & 0.8 & 7.6 & 14.4 & 46.6 & 3.4 & 7.6 & 0.8 & 0.8 & 5.1 & 1.7 & 3.4 & 2.5 & 1.7 & 2.5 & 0.8 \\
\hline
\end{tabular}




\section{Acknowledgements}

Thanks to Sunita Mahat for assistance with registration and databasing, Jean-Claude Stahl for help with translating Holyoak and Thibault (1984) and Trevor Worthy for commenting on the manuscript.

\section{References}

Hall, J.V. 1869. On the island of Rapa. Transactions and Proceedings of the New Zealand Institute $1: 128-134$.

Holyoak, D.T. and Thibault, J-C. 1984. Contribution à L'étude des oiseaux de Polynésie Orientale. Mémoires du Muséum National D'Histoire Naturelle Série A, Zoologie, 127:1-209.

Jenkins, J.A.F. and Cheshire, N.G. 1982. The black-winged petrel (Pterodroma nigripennis) in the south-west Pacific and the Tasman Sea. Notornis 29:293-310.

Marchant, S. and Higgins, P.J. 1990 (co-ordinators). Handbook of Australian, New Zealand and Antarctic Birds, Volume 1, Ratites to Ducks. Oxford University Press, Melbourne.

Murphy, R.C. and Snyder, J.P. 1952. The "Pealea" phenomenon and other notes on storm petrels. American Museum Novitates 1596:1-16.

Pratt, H.D., Bruner, P.L. and Berrett, D.G. 1987. A Field Guide to the Birds of Hawaii and the Tropical Pacific. Princeton University Press, New Jersey.

Steadman, D.W. 1995. Prehistoric extinctions of Pacific Island birds: biodiversity meets zooarchaeology. Science 267:1123-1131.

Tennyson, A.J.D. 1991. The black-winged petrel on Mangere Island, Chatham Islands. Notornis 38:111-116.

Tennyson, A.J.D. and Martinson, P. 2006. Extinct Birds of New Zealand. Te Papa Press, Wellington.

Thibault, J-C. and Varney, A. 1991a. Numbers and habitat of the Rapa fruit-dove Ptilinopus huttoni. Bird Conservation International 1:75-81.

Thibault, J-C. and Varney, A. 1991b. Breeding seabirds of Rapa (Polynesia): numbers and changes during the 20th century. Bulletin of the British Ornithologists' Club, 111(2):70-77.

Worthy, T.H. 2001. A giant flightless pigeon gen. et sp. nov. and a new species of Ducula (Aves: Columbidae), from Quaternary deposits in Fiji. Journal of the Royal Society of New Zealand 31:763-794. 